1 ICAP at Columbia, Mailman School of Public Health, Columbia University, New York, NY, USA

2 Departments of Epidemiology and Medicine, Columbia University, New York, NY, USA

Correspondence to: J Justman jij2158@cumc.columbia.edu

Cite this as: BMJ 2020;370:m2655 http://dx.doi.org/10.1136/bmj.m2655 Published: 3 July 2020

\title{
Antibody testing for coronavirus disease 2019: not ready for prime time
}

\author{
The tests need work, and fundamental questions remain about immunity
}

Yen T Duong, ${ }^{1}$ Connor G Wright, ${ }^{1}$ Jessica Justman ${ }^{1,2}$

The development of serology testing to detect antibodies to the virus responsible for coronavirus disease 2019, severe acute respiratory syndrome coronavirus 2 (SARS-CoV-2), first reported by Zhu and colleagues, ${ }^{1}$ and followed soon after by many others, has been enthusiastically hailed as the key to monitoring and responding to the pandemic, including the restart of economic activities. This enthusiasm reflects the hope that antibodies to SARS-CoV-2 will provide protective and long lasting immunity and allow recovered individuals to resume their daily lives. Unfortunately, we do not yet know what the presence of detectable antibody signifies, either for an individual or for a population, how durable it will be, or how much serologic variation to expect among different groups, such as those who had an asymptomatic infection.

\section{Not good enough}

In a linked paper, Bastos and colleagues (doi:10.1136/bmj.m2516) provide a much needed review of the performance of serological assays to accurately detect antibodies to SARS-CoV-2. ${ }^{2}$ They meta-analyzed 40 studies according to type of antibody test (enzyme linked immunosorbent assays (ELISAs), lateral flow immunoassays (LFIAs), and chemiluminescent immunoassays (CLIAs)), and for each type, determined the average or pooled sensitivity and specificity and assessed the studies for risk of bias. Only four of the 40 studies included outpatients and only two studies assessed LFIAs at the point of care.

The pooled sensitivities had a wide range, with higher sensitivity in the CLIAs (97.8\%) and lowest in the LFIAs $(66.0 \%)$ and were higher with increased time after symptom onset. The range for specificities was narrower, from $96.6 \%$ to $99.7 \%$. The risk of patient selection bias affected nearly every study.

It is important to keep in mind that pooling sensitivities makes it difficult to determine how well tests perform at detecting antibody early or late in the course of illness (reported as $26.7 \%$ for samples collected during the first week versus $78.4 \%$ for samples collected beyond the third week for ELISAs). Pooling also hinders the ability to identify individual tests that might perform well in testing algorithms, described below. Ideally, test performance should be compared according to the viral antigen used in each assay, such as the $\mathrm{N}$ nucleocapsid or the $\mathrm{S}$ spike protein, since antibodies against the spike protein are thought to correlate with neutralizing titers. ${ }^{3}$ Nonetheless, the key message of the review aligns with the conclusion of another systematic review ${ }^{4}$ published last week: serologic assays for SARS-CoV-2 antibodies, especially point-of-care tests, are not ready for widespread use by clinicians, the general public, or policy makers.

It is unlikely that any single serologic test will provide the kind of reliable and accurate information that are needed to fully understand the current pandemic. As Bastos and colleagues and others have indicated, ${ }^{5}$ tests with low specificity provide more false positives than true positives in low prevalence settings, resulting in unacceptably low positive predictive values. To overcome the poor performance of a single serologic test, an algorithm should be considered that combines two or more tests $\left(\mathrm{eg},{ }^{6}\right)$. For example, in a $5 \%$ prevalence setting, screening with one of the more sensitive ELISAs reviewed by Bastos and colleagues ( $96.0 \%$ sensitivity, $99.2 \%$ specificity $)^{7}$ and then using a more specific test $(85.0 \%$ sensitivity, $100 \%$ specificity) ${ }^{8}$ as the confirmatory test would increase positive predictive value from $55 \%$ to $100 \% .{ }^{9}$ Such an algorithm would still fail to identify antibodies in samples collected within the first 14 days of symptom onset and require follow-up testing at a later date (more than three weeks after symptom onset).

\section{Independent evaluation}

In the early months of the outbreak, the global market was flooded with antibody tests of unproven test performance, and various governments, including those of the UK and India, purchased large quantities of ineffective antibody tests. ${ }^{10-12}$ In the US, the Food and Drug Administration reversed course in May and mandated emergency use authorizations for all commercially available serologic test kits with a test performance of $90 \%$ or more sensitivity and $95 \%$ or more specificity, ${ }^{13}$ but the damage had been done and contributed to surveillance data of uneven quality. Critical independent evaluations of antibody tests are currently underway by the FDA and other organizations $^{14-16}$ to provide researchers, public health officials, and others with better data for decision making. Ideally, these evaluations should all use the same specimen panels containing reverse transcriptase polymerase chain reaction confirmed SARS-CoV-2 positive and negative plasma. Such specimen panels are a valuable tool for both test kit developers and evaluators, and global health institutions should make them widely available.

As this review makes clear, there is more work to do on serologic testing. Assays must be optimized further, independently validated, and used in an algorithm format to achieve the highest possible accuracy for decision making, especially at an individual level. 
High quality antibody tests have the potential to provide important information about prior infection, and the prevalence of antibodies in a population might help us to understand the extent of the epidemic and the role of transmission from asymptomatic individuals. Further research is needed to address fundamental questions about the presence of antibodies and the degree and durability of protection. Until then, even the most optimal serologic test will be of limited utility.

Competing interests: The BMJ has judged that there are no disqualifying financial ties to commercial companies. The authors declare the following other interests: none.

The BMJ policy on financial interests is here: https://www.bmj.com/sites/default/files/attachments/resources/2016/03/16-current-bmj-education-coi-form.pdf.

Provenance and peer review: Commissioned; not externally peer reviewed.

1 Zhu N, Zhang D, Wang W, etalChina Novel Coronavirus Investigating and Research Team. A Novel Coronavirus from Patients with Pneumonia in China, 2019. N Engl J Med 2020;382:727-33. doi: 10.1056/NEJMoa2001017. pmid: 31978945

2 Lisboa Bastos M, Tavaziva G, Abidi SK, etal. Diagnostic accuracy of serological tests for covid-19: systematic review and meta-analysis. BMJ2020;370:m2516doi: 10.1136/bmj.m2516

3 Premkumar L, Segovia-Chumbez B, Jadi R, etal. The receptor binding domain of the viral spike protein is an immunodominant and highly specific target of antibodies in SARS-CoV-2 patients. Sci Immunol 2020;5:. doi: 10.1126/sciimmunol.abc8413. pmid: 32527802

4 Deeks J), Dinnes J, Takwoingi Y, etalCochrane COVID-19 Diagnostic Test Accuracy Group. Antibody tests for identification of current and past infection with SARS-CoV-2. Cochrane Database Syst Rev 2020;6:. doi: 10.1002/14651858.CD013652. pmid: 32584464

5 Bond K, Nicholson S, Lim S, et al. Evaluation of serological tests for SARS-CoV-2: Implications for serology testing in a low-prevalence setting. medRxiv. 20118273 [Preprint]. 2020 doi: 10.1101/2020.05.31.20118273

6 Branda JA, Body BA, Boyle J, etal. Advances in Serodiagnostic Testing for Lyme Disease Are at Hand. Clin Infect Dis 2018;66:1133-9. doi: 10.1093/cid/cix943 pmid: 29228208

7 Freeman B, Lester S, Mills L, et al. Validation of a SARS-CoV-2 spike protein ELISA for use in contact investigations and sero-surveillance. bioRxiv 057323 [Preprint]. 2020 doi: 10.1101/2020.04.24.057323

8 Adams ER, Ainsworth M, Anand R, et al. Antibody testing for COVID-19: A report from the National COVID Scientific Advisory Panel. medRxiv 20066407 [Preprint]. 2020 doi: 10.1101/2020.04.15.20066407

9 U.S. Food and Drug Administration. EUA Authorized Serology Test Performance. 2020 www.fda.gov/medical-devices/emergency-situations-medical-devices/eua-authorized-serologytest-performance [accessed 30 Jun 2020].

10 Andersson M, Low N, French N, etal. Rapid roll out of SARS-CoV-2 antibody testing-a concern. BMJ 2020;369:m2420. doi: 10.1136/bmj.m2420. pmid: 32580928

11 BBC News. Coronavirus: India cancels order for 'faulty' China rapid test kits 2020 www.bbc.com/news/world-asia-india-52451455 [accessed 1 July 2020].

12 Hodgson C, Parker G. UK government admits Covid-19 antibody tests don't work. Financial Times 2020.

13 US Food and Drug Administration. Insight into FDA's Revised Policy on Antibody Tests: Prioritizing Access and Accuracy. FDA, 2020.

14 US Food and Drug Administration. Independent Evaluations of COVID-19 Serological Tests. FDA, 2020 https://open.fda.gov/apis/device/covid19serology/ [accessed 30 Jun 2020].

15 COVID Testing Project. COVID-19 Testing Project. 2020 https://covidtestingproject.org/ [accessed 29 Jun 2020].

16 FIND. FIND Evaluation Update: SARS-CoV-2 Immunoassays. 2020. www.finddx.org/covid19/sarscov2-eval-immuno/ [accessed 30 Jun 2020].

This article is made freely available for use in accordance with BMJ's website terms and conditions for the duration of the covid-19 pandemic or until otherwise determined by BMJ. You may use, download and print the article for any lawful, non-commercial purpose (including text and data mining) provided that all copyright notices and trade marks are retained. 